\title{
TAXONOMICAL NOTES ON MYCOGENOUS FUNGI I
}

\author{
SHUN-ICHI UDAGAWA AND YOSHIKAZU HORIE* \\ Departmeni of Microbiology, National Instituie of Hygienic \\ Sciences, Kamiyoga 1-chome, Setagaya-ku, Tokyo 158 \\ and
}

Institute of Food Microbiology, Chiba University*, Izumi-cho 3-chome, Narashino-shi, Chiba-ken 275

(Received December 1, 1970)

\begin{abstract}
As a result of studies on mycogenous fungi of mushrooms, mainly in two forests located in northern and cen ral Japan, a total of 17 species representing 15 genera of Ascomycetes and Hyphomycetes are reported. Cephalotheca splendens is described as a new Ascomycete, distinct from the previously known species of the genus in its yellowish mycelial felt on which shiny black cleistothecia are borne and olive brown, discoid ascospores, measuring $3-4 \times 2.5-3.5 \times 2-2.5 \mu$. Included in the report are $5 \mathrm{im}-$ perfect fungi new to Japan, and several additional isolates.
\end{abstract}

A taxonomical study of mycogenous or fungicole fungi is never of modern problem in the world. In the most recent review, ARNOLD (1) listed up about 140 species as fungicolous, one of the ecologically interesting habitants. Extensive bibliography has been compiled also by Nicot (2). In Japan, TUBAKI (3) described 24 species of Hyphomycetes in mushrooms collections from many localities, and about a decade later KomATSU and HASHIOKA (4) reported three groups as disease-causing organisms on cultivated mushrooms, especially on shiitake (Lentinus edodes). Other than these reports, however, little if anything seems to have been published about Japanese and the neighboring Pacific sources. This report is the first in a series presenting results of comprehensive survey, in an attempt to clarify taxonomical problems in some peculiar taxa and contributing to the knowledge of distribution of the mycogenous fungi in these areas of the Pacific.

\section{MATERIALS AND METHODS}

Most of the samples investigated were found in the Nakagawa experimental forest (mainly coniferous) of Hokkaido University, Otoineppu, Hokkaido, northern part of Japan, and in natural forests of the Nikko National Park, Tochigi Pref., central part of Japan. 
The materials were washed twice or more with sterile water containing $0.01 \%$ chloramphenicol. Then, jsolation was made by placing the materials on filter papers in moist chambers and incubating them at room temperature. Examination of the chamber was made at weekly intervals over a three month period. When fruiting structures appeared on the material, spores from a single sporophore were transferred to potato-dextrose agar or oat-meal agar on which the isolates were maintained in pure culture.

Cultural observation was made by using plates grown on the following media at $25^{\circ}$ under a continuous fluorescent light: potato-dextrose agar, potato-carrot agar, oat-meal agar with wheat germ powder, and V-8 juice agar. For hardly sporulating species, two of the special media tried were as follows: polypore extract agar ( $200 \mathrm{~g}$ polypore flour was infused with 1 liter of distilled water) and $1 \%$ glucose agar with gas-sterilized pieces of polypore blocks.

\section{DESCRIPTIONS OF NEW OR NOTEWORTHY RECORDS}

Cephalotheca splendens sp. nov.

(Figs. 1 and 9-11)

Cleistotheciis superficialibus, sparsis, primum in strato hypharum sulphurearum vel albarum immersis, deinde emergentibus nigris et glabris, nitentibus, globosis, $325-500 \mu$ diam., non ostiolatis, postremo in partibus polygonis disruptis. Peridio nigro, tenui, membranaceo-carbonaceo, ex cellulis elongatis composito. Ascis irregulaliter dispositis, octosporis, hyalinis vel pallido-brunneis, $6-7 \times 5-6 \mu$, valde evanescentibus. Ascosporis novellis hyalinis, deinde olivaceo-brunneis, opacis, frequenter conglobatis, continuis, discoideis, globosis ab fronte visis, ovatis ab latere visis, $3-4 \times 2.5-3.5 \times 2-2.5 \mu$, aliquando $a b$ uno latere concavis, levibus, crassitunicatis.

Mycelio prostrato, hyalino, septato, $1.5-2.4 \mu$ diam., ramoso, saepe funiculosis. Conidiophoris obscuris; cellulis sporogenis simplicibus vel saepe reductis. Sporophoris tenuibus, simplicibus vel pauci ramosis, $18-44 \times 1.5-2.5 \mu$, apicem versus attenuatis. Conidiis hyalinis, oblongis vel allantoideis, $3.5-5 \times$ $1-1.5 \mu$, non septatis, levibus, in massa mucosa conglomeratis.

Coloniis in agaro decocto solanum tuberosum celeriter crescentibus, tenuibus et paene campestribus leviter funiculosis, sulphureo-aurantiacis, reverso aurantiaco.

Typus: ex Elfvingia applanata, Otoineppu, Nakagawa-gun, Hokkaido, Japan, Herb. NHL 22441.

Cleistothecia superficial, scattered, at first invested with a white to yellow mycelium, then becoming black and glabrous, shining, spherical, 325-500 $\mu$ in diam., astomous, attached firmly by dark brown rhizoids, at maturity breaking into polygonal plates along well-defined suture lines. Cleistothecial peridium black, thick-walled, membranaceous-carbonaceous, consisting of long elongated cells. Asci irregularly arranged in the cavity, 8-spored, hyaline to pale brown, 6-7 $75-6 \mu$, very evanescent. Ascospores at first hyaline, later 
becoming olive brown and opaque, often conglomerate and black in masses, continuous, discoid, globose on face view and ovate on side view, (2.5-) 3-4 $(-5) \times 2.5-3.5 \times 2-2.5 \mu$, sometimes inequilateral due to collapse, with walls smooth and thick.

Conidial state of radulaspore-type. Mycelium prostrate, hyaline, septate, $1.5-2.4(-3.3) \mu$ in diam., irregularly and highly branched, often united in funicles. Conidiophores not obvious; sporogenous cells simple, consisting of sporophores usually borne singly along the aerial hyphae, or often reduced to short denticles on the hyphae. Sporophores slender, simple or few branched, (6-) $18-44 \times 1.5-2.5 \mu$, gradually tapering to the apex. Conidia hyaline, oblong to allantoid, $3.5-5 \times 1-1.5 \mu$, rounded at both ends or somewhat pointed at one end, non-septate, smooth-walled, accumulate in slimy balls up to $6-14 \mu$ in diam.

Colonies on potato-dextrose agar growing rapidly, thin and almost plane, slightly faniculose, with a thin mycelial felt, conidial structures evenly scattered but cleistothecium production commonly occurring very late (after 3 months) and not uniformly throughout the whole colony, yellowish orange, reverse orange.

On potato-carrot agar growing rather rapidly, funiculose, thin, with surface growth showing more abundant production of aerial hyphae and conidial structures than on PDA but cleistothecia less produced, white to pale yellow.

At $37^{\circ}$, growth is nil.

Habitat: on Elfvingia applanata, Otoineppu, Nakagawa-gun, Hokkaido, Japan, Sept. 6-8, 1969, NHL 2441 (Herb. No. 22441, type). Living type cultures are deposited in the Centraalbureau voor Schimmelcultures, Baarn, and Institute for Fermentation, Osaka.

This species is distinguished from others of the genus by its yellowish mycelial felt, and ascospores that are discoid, olive brown, and $3-4 \times 2.5-3.5$ $\times 2-2.5 \mu$ (BоOTH, 5). Ovate ascospores, of approximately the same size, are also found in C. palearum RICHON (6). No cultures or exsiccata of the latter species can be traced, but the description indicates clearly that it has palecolored cleistothecia and much larger asci. Richon's inclusion of Myxotrichum in the description was mistakenly interpreted in the field as imperfect state because of its adjacent habitat. The conidial form of our new taxon is similar to those of $C$. purpurea (Shear) Chesters and $C$. reniformis Sacc. et Therry (7), but the ascospores of both of these species are reniform to allantoid instead of discoid. Very recently, these two cephalothecoid species have been treated under Fragosphaeria by MALLOCH and CAIN $(8)$, while it may be still in a tentative state.

Nectria gliocladioides Smalley et Hansen, in Mycologia, 40, 529 (1957).

St. conid. Gliocladium roseum (Link) Bainier, in Bull. Soc. Mycol. France, 


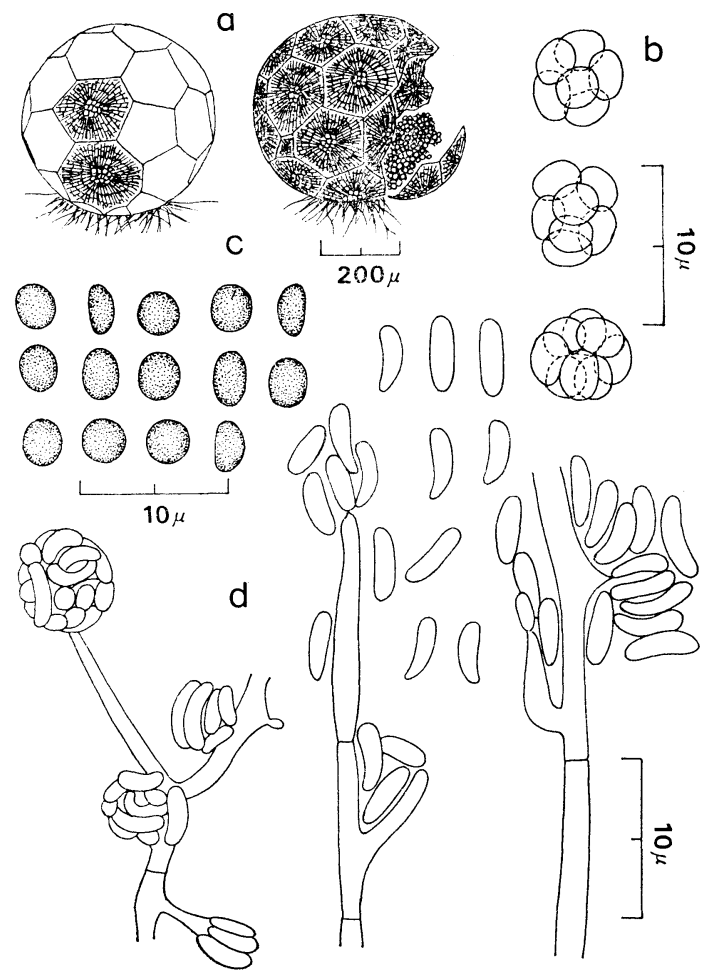

Fig. 1. Cephalotheca splendens.

a. Cleistothecia, b. Asci, c. Ascospores, d. Conidial structures and conidia.

23, 111 (1907); Tubaki, in Nagaoa, 4, 8 (1954); Morquer, et al., in Bull. Soc. Mycol. France, 79, 137-241 (1963).

Penicillium roseum Link, 1816; Verticillium duboys Fo:̈x, 1923; V. foëxii van Beyma, 1928; V. pulverulentum Gouwentak, 1924; V. rhizophagum Tehon et Jacobs, 1936.

Perithecia superficial, often caespitous on an inconspicuous, erumpent, pulvinate stroma which is formed as a fascicle of hyphae, light yellowish orange, spherical to subspherical, $200-340 \mu$ in diam., with a minute, nonpapilliform to papilliform ostiole, glabrous; peridium somewhat warty, translucent, membranaceous, consisting of pale yellow angular cells measuring 10-18 $\times 8-14 \mu$. Asci cylindrical or clavate, 8-spored, 52-70 $\times 4-7 \mu$, apex rounded and thickened with a distinct pore, tapering slightly to a short stipe; paraphyses lacking. Ascospores obliquely uniseriate, sometimes becoming biseriate above, elliptical, $10-12 \times 3-4 \mu$, hyaline, transversely one-septate, slightly constricted at the septum.

Conidial fructifications of two types. Verticillium state abundantly pro- 


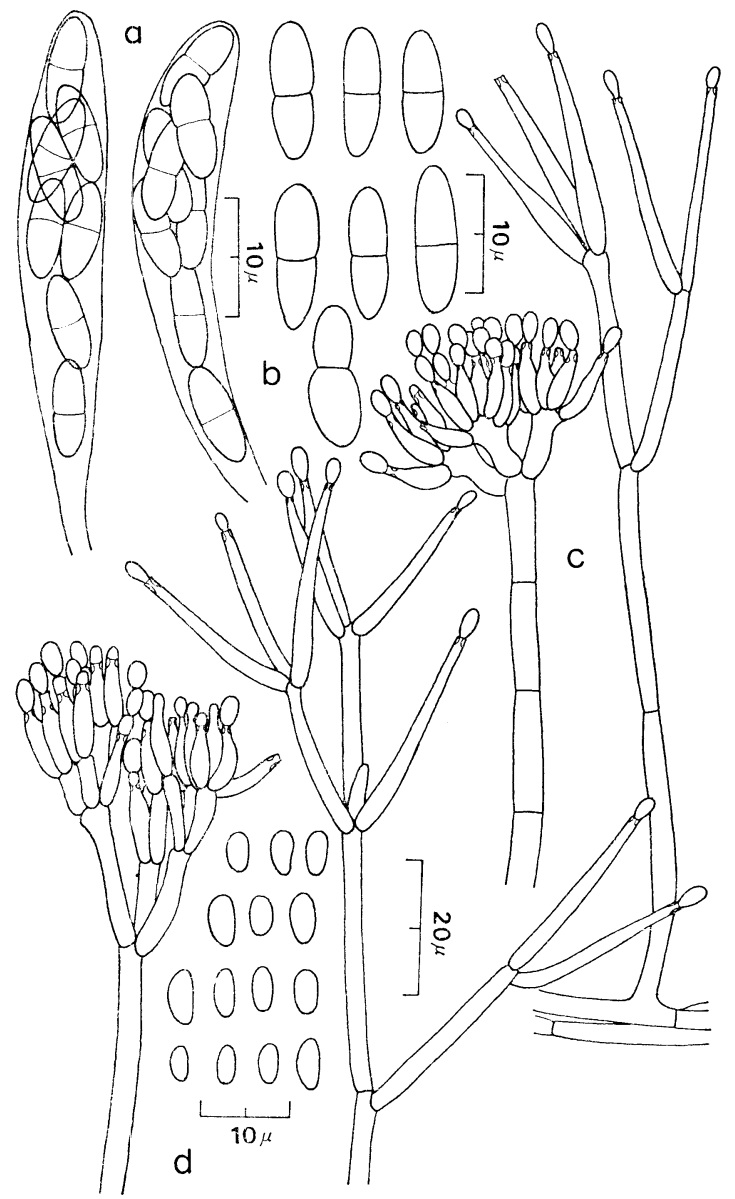

Fig. 2. Nectria gliocladioides.

a. Asci, b. Ascospores, c. Two types of conidial structures, d. Conidia.

duced on common media such as PCA; conidiophores hyaline, slender, 30$200 \times 3-4.5 \mu$, septate, smooth-walled, verticillately branched. Phialides in verticils of $2-4,20-38 \times 2-3 \mu$. Conidia hyaline, elliptical to ovate, $4-8(-11)$ $\times 2-3.6 \mu$, smooth-walled, aseptate. Gliocladium state also associated with the perithecia and the Verticillium state, arising from aerial hyphae or ropes of hyphae. Conidiophores straight, up to $100 \times 4-5 \mu$, hyaline, septate, $2-3$ times branched, with walls smooth or roughened. Branches $20-32 \times 3.5 \mu$. Metulae irregularly borne, $9-10 \times 2.4-3 \mu$, in groups of $6-8$. Phialides cylindrical, in compact clusters of $3-5,10-20 \times 2-2.5 \mu$, bearing conidia in gelatinous balls or masses. Conidia as described above in dimensions. 
Cultures on the common media spreading broadly, floccose to funiculose, conidial structures usually abundantly produced, white to pale orange or pale yellow, perithecial primordia present in limited numbers, buried in a thick mycelial felt, reverse mostly pale yellowish brown.

At $37^{\circ}$, growth is nil.

Habitat: on Xylaria polymorpha, Minakami, Tone-gun, Gunma Pref., Japan, Nov. 16, 1969, NHL 2443, and on Fomes fomentarius, Otoineppu, Nakagawa-gun, Hokkaido, Japan, Sept. 6-8, 1969, NHL 2451; on Elfvingia applanata, collected at the same locality as NHL 2451 (conidial state only).

In Japan, $N$. gliocladioides with its imperfect form $G$. roseum is well known as an associate with decaying fructifications of higher fungi, particularly recovering by TUBAKI on Phlogiotis helvelloides and other hosts (9).

Arthrobctrys cladcdes Drechsler var. macroides Drechsler, in Mycologia, 36, 144 (1944); Haard, in Mycologia, 60, 1151 (1968).

(Fig. 3)

Trichothecium cladodes var. macroides Soprunov, 1958.

Colonies on potato-carrot agar spreading broadly, floccose to somewhat funiculose, consisting of a very thin vegetative growth, conidial structures abundantly produced, white to pale pink, reverse uncolored.

Mycelium hyaline, $2-5.5(-7) \mu$ in diam., branched, septate. Conidiophores erect, arising terminally or laterally from the substratum or ropes of hyphae, hyaline, subulate, $180-285 \mu$ in length, $4-5.5 \mu$ in diam. at the base tapering to $2-3 \mu$ below swollen tip, smooth-walled, mostly non-nodular, but occasionally with a weak nodal development, often bearing a loose, short, apical branching system. Conidiophore tips irregularly expanded, bearing up to 620 sterigmata-like warty protuberances each with a single conidium. Conidia blastogenous, forming a distinct capitate head at the conidiophore tip, hyaline, obovate to oblong-ellipsoid, $16-26 \times 8-12 \mu$, one-septate, slightly constricted at the septa, smooth-walled, rounded distally, apiculate and pedicellate at the proximal end, with the proximal cell usually slightly smaller than the distal cell, measuring $7-10 \mu$ in length. Chlamydospores not produced. Conidia in the natural substratum slightly larger, $20-27.5(-30) \times 10-14 \mu$; the proximal cell $7.5-14 \mu$ in length. Predaceous networks present.

On V-8 juice agar similar to those on PCA but usually rather more floccose.

At $37^{\circ}$, growth is nil.

Habitat: on Elfvingia applanata, Otoineppu, Nakagawa-gun, Hokkaido, Japan, Sept. 6-8, 1969, NHL 2442.

A. cladodes var. macroides is distinguished from the other Arthrobotrys species by its branched conidiophores and rather smaller conidia that are borne on wart-like sterigmata. It may at first be confused with $A$. superba Corda in conidial shape and dimensions, but the conidiophores of the latter species are normally with nodal development and unbranched. So far as we are aware, A. cladodes var. macroides has not been found in Japan. 


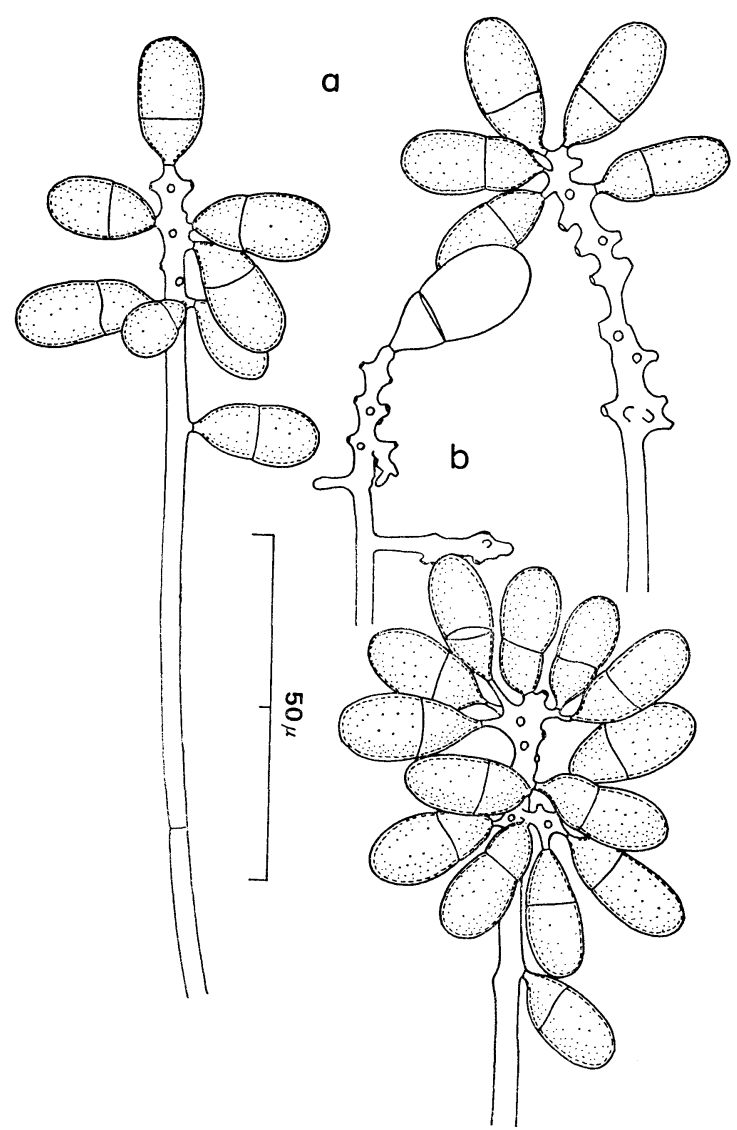

Fig. 3. Arthrobotrys cladodes var. macroides.

a. Conidial structures, b. Branched head.

Doratomyces microsporus (Sacc.) Morton et G. Smith, in C.M.I. Mycol. Pap., 86, 77 (1963).

(Fig. 12)

Stysanus microsporus Sacc., 1878; Graphium graminum Cooke, 1887.

Colonies on potato-carrot agar growing rather rapidly, at first rather floccose, but quickly approaching deep velvety from the production of abundant coremia, dark olive gray to olive black, reverse dark gray, occasionally showing pale reddish purple color. Mycelium composed of hyaline to pale brown, septate, branched, 1-2 $\mu$ wide hyphae which may commonly aggregate forming ropes. Conidial structures arising directly from the substratum or from the basal mycelium, mostly as typical coremia. Coremia dark olivaceous brown, $250-1,200 \times 8-32 \mu$, with upper fertile regions globose to cylin- 
drical, occupying the upper $1 / 3-1 / 2$ of the total height; stalks slender, composed of compactly parallel hyphae, measuring $1-2.5 \mu$ in diam., occasionally branched. Annellophores terminally borne on the coremia, short cylindrical, $6.5-9 \mu$ long, with slightly swollen base $2-3 \mu$ in diam., narrowing rather abruptly to annellated zone $0.8-1 \mu$ in diam. Conidia pale gray to black in mass, ovate, $3-4.5(-5) \times 2-3 \mu$, base truncate, apex rounded or more commonly pointed, smooth-walled, bearing short chains.

On V-8 juice agar growing rapidly, floccose to funiculose.

At $37^{\circ}$, growth is nil.

Habitat: on Coriolus hirsutus, Otoineppu, Nakagawa-gun, Hokkaido, Japan, Sept. 6-8, 1969, NHL 2446.

D. microsporus, a widely distributed species in nature, commonly found in soil and on a variety of plant substrates, though it has only rarely been reported from air (10) and on commercial media for Pholiota nameko (11) in Japan.

Doratomeces putredinis (Corda) Morton et G. Smith, in C.M.I. Mycol. Pap., 86, 83 (1963).

(Fig. 4, 13)

Stysanus putredinis Corda, 1839; Graphium putredinis (Corda) Hughes, 1958; Synpenicillium album Costantin, 1888; Penicillium costantini Bainier, 1906; Corcmium album (Cost.) Sacc. et Traverso, 1913; Scopulariopsis costantini (Bain.) Dale, 1914; Acaulium fulvum Sopp, 1912.

Colonies on V-8 juice agar growing rather restrictedly, plane, funiculose to fasciculate, with vegetative mycelium thin and white, later becoming pale yellowish brown (pale buff) with the development of abundant fruiting penicillate structures and small coremia, with aerial hyphae usually showing definite ropiness, reverse dull yellow orange.

Mycelium composed of hyaline, smooth-walled, septate, branched, $2-5(-7)$ $\mu$ wide hyphae which may be aggregated into prominent funicles or ropes. Conidial structures varying from complex penicillate heads or well-developed coremia to simple annellophores borne on trailing hyphae. Conidiophores hyaline, septate, smooth-walled, arising from the substratum or aerial hyphae as perpencicular branches, the former ranging up to 70 or more $\times 4-6 \mu$, with numerous metulae and branches, the latter ranging $8-14(-20) \times 3-4 \mu$, with a cluster of 4-8 annellophores. Annellophores with swollen base and tapering abruptly at the tip into an annellated zone, $8-18 \times 2.5-3.5 \%$ at the broadest part. Conidia ovate to elongate, $4.2-5.8 \times 1.5-3 \mu$, rounded at the apex and truncate at the base, with walls smooth, borne in chains forming columns up to $400-500 \mu$ in length. Coremia abundantly produced on the natural substratum, white, with stalks composed of compact parallel strands of hyaline hyphae, forming a columnar head, 600-1,000 or more $\times 20-60 \mu$, heavily sporing over the upper $1 / 4$.

On potato-dextrose agar growing restrictedly, funiculose to somewhat powdery, comparatively tough, and commonly developing pale yellow orange 


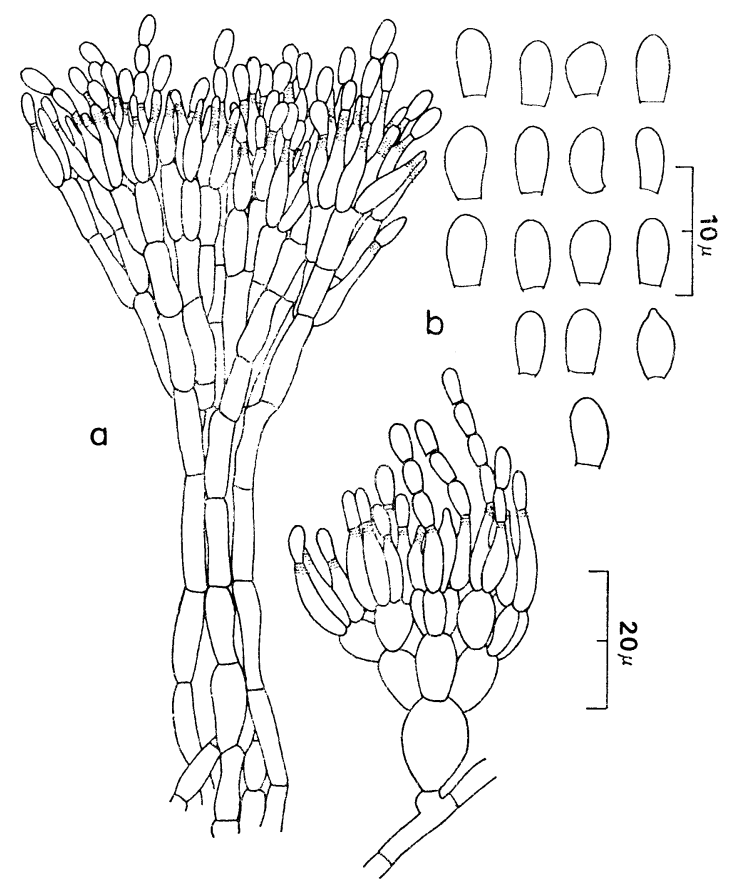

Fig. 4. Doratomyces puiredinis.

a. Coremium and conidial structure, b. Conidia.

(ivory) shades, conidial structures abundant but with coremia not produced, reverse grayish yellow brown.

At $37^{\circ}$, growth is nil.

Habitat: on Macrolepiota procera, Sugadaira, Sanada-machi, Chiisagatagun, Nagano Pref., Japan, Oct. 2-3, 1969, NHL 2440.

D. putredinis is unique among species of Doratomyces in having white colonies and loosely compacted coremia. We know of no previous collection from Japan.

Oidium conspersum (Link) Linder, in Lloydia, 5, 176 (1942).

Acladium conspersum Link, 1809; Sporotrichum conspersum (Link) Fr., 1829 ; ?Amphiblistrum hypochnoides Corda, 1837; Rhinotrichum repens Preuss, 1862; Rhinotrichum sulfureum Ellis et Ev., 1884; Rhinocladivm olivaceum Bresadola, 1900; Rhinotrichum bicolor Sumstine, 1911; Rhinotrichum nooblesiae Sumstine, 1937.

Mycelium prostrate, hyaline, branched, 6-10 $\mu$ in diam., smooth-walled, often fusing. Conidiophores long, erect, hyaline, $160-320 \mu$ in length, 8-11 $\mu$ in diam. near the base, unbranched or irregularly branched in the lower parts, septate, slightly tapering to a bluntly rounded apex, with a long, more 


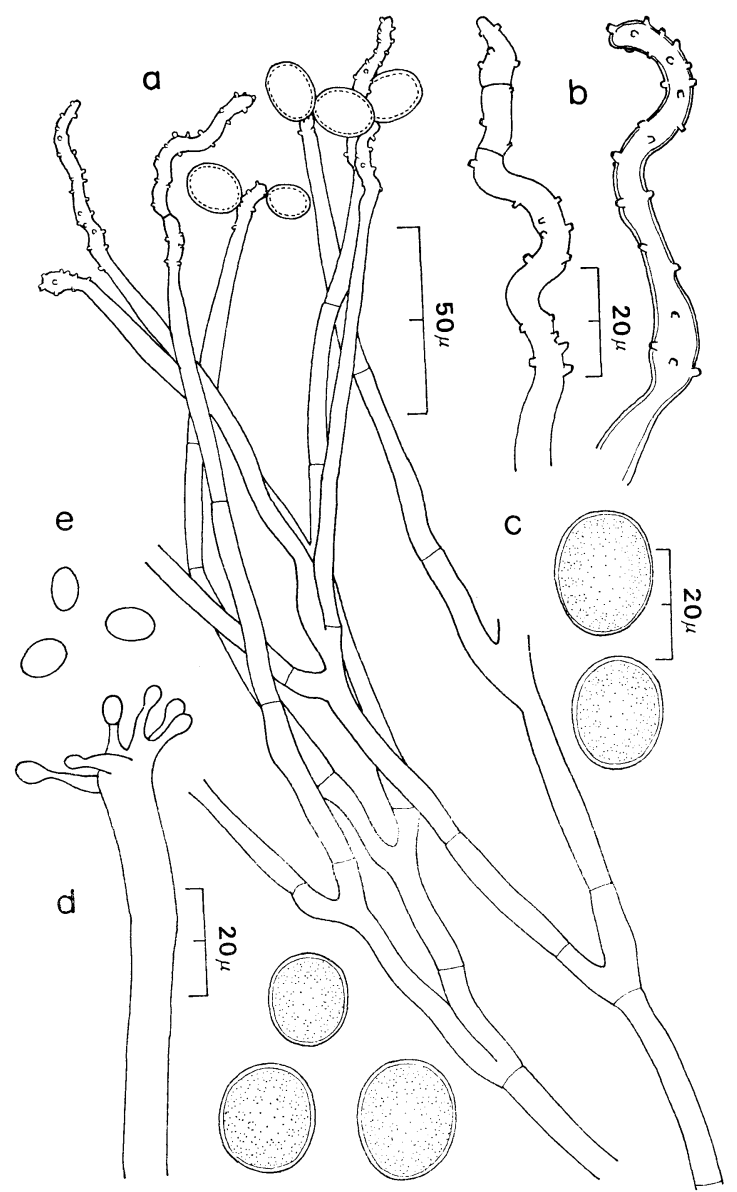

Fig. 5. Oidium conspersum.

a. Conidial structures, b. Terminal portions of conidiophores, c. Conidia, d. Basidium, e. Spores.

or less geniculate, sporogenous region measuring 60-120 $\mu$ long, often secondarily proliferating. Sporogenous teeth denticulate, evident as cylindrical scars, truncate, stout, $1.5-3.5 \times 1.5-2 \mu$, producing acropleurogenously on upper cells of the conidiophore above the basal part. Vesicles none or indistinct. Conidia borne singly on the teeth, hyaline to pale yellow (strawcolored), globose or broadly ovate, $12-22 \times 10-19 \mu$, rather thick-walled, often with slightly truncate base at point of attachment. Sclerotia-like bodies produced, composed of a compact mycelial strand, pale yellow, spherical, $60-80 \mu$ in diam. 
Habitat: on Trametes dickinsii, Nikko National Park, Nikko-shi, Tochigi Pref., Japan, Oct. 30-31, 1969, NHL Herb. No. 22472.

O. effusum (B. et C.) Linder is closely related to this species but has abundant clamp connections at the conidiophores and the globose conidia. O. ellipsosporum HOLUBOVÁ-JECHOVÁ (12) has shorter conidiophores with large sporogenous teeth. The following basidial state of our collection is too fragmentary, and we would retain this material in imperfect fungi until a study of the sexual development for a further collection can be completed: "Basidia short, up to $65-100 \times 6-12 \mu$, more or less clavate, sometimes swollen near the apex, provided with $4-6(-8)$ sterigmata. Sterigmata often divergent, somewhat curved, $5-20 \times 2.4-3 \mu$. Spores hyaline, ovate, $7-10 \times$ $4.5-6 \mu$, with a truncate base, smooth-walled."

Phialophora verrucosa Medlar, in Mycologia, 7, 203 (1915); van Beyma, in Antonie van Leeuwenhoek, 9, 67 (1943); Wang, Fungi of palp and paper in New York, p. 76 (1965); Schol-Schwarz, in Persoonia, 6, 90 (1970). (Fig. 14)

Mycelium hyaline to pale olivaceous, septate, smooth-walled, 1.5-3.5 $\mu$ in diam., branched, often aggregated in ropes. Conidial structures consisting of single phialides borne on the aerial hyphae, or groups of a few phialides clustered on short conidiophores, $6-22 \times 2.4-4 \mu$. Phialides olivaceous brown, cylindrical to flask-shaped, $4.5-14(-25) \times 2.5-3 \mu$, with a distinct apical collarette; the collarettes funnel-shaped with flaring edge, $2.4-4 \times 2.4-4.5(-6) \mu$. Conidia endogenously produced and aggregated in balls at the phialide apex, hyaline, subglobose at first, then becoming ovate to elliptical, $2.4-5 \times 1.5-2$ $(-2.4) \mu$, with rounded ends, smooth-walled. Moniliform hyphae also present, consisting of chains of swollen cells.

Cultures on potato-carrot agar growing restrictedly, velvety to slightly funiculose, close-textured, consisting of a thin basal felt bearing abundant conidial structures, grayish black to dark olive green or dark olive gray, reverse greenish black to black.

On Czapek agar growing somewhat more slowly, yeast-like in colony appearance.

At $37^{\circ}$, very little growth.

Habitat: on Trametes dickinsii, Nikko National Park, Nikko-shi, Tochigi Pref., Japan, Oct. 30-31, 1969, NHL 2450.

The isolate is closely related to $P$. melinii (Nannfelt) Conant in colony color and conidial shape, but more approximates $P$. verrucosa in growth rate and conidial dimension. P. fastigiata (Lagerb. et Melin) Conant is quite similar, but here the growth rate is also rapid and collarettes of phialides are smaller. In Japan, Komatsu (11) recorded the species from the commercial medium for Pholiota nameko.

Rhirecladiella elatior Mangenot, in Rev. Gén. Botan., 59, 477-519 (1952); Schol-Schwarz, in Antonie van Leeuwenhoek, 34, 148 (1968); Dal Vesco and Peyronel, in Allionia, 14, 38 (1968).

(Figs. 6, 15) 


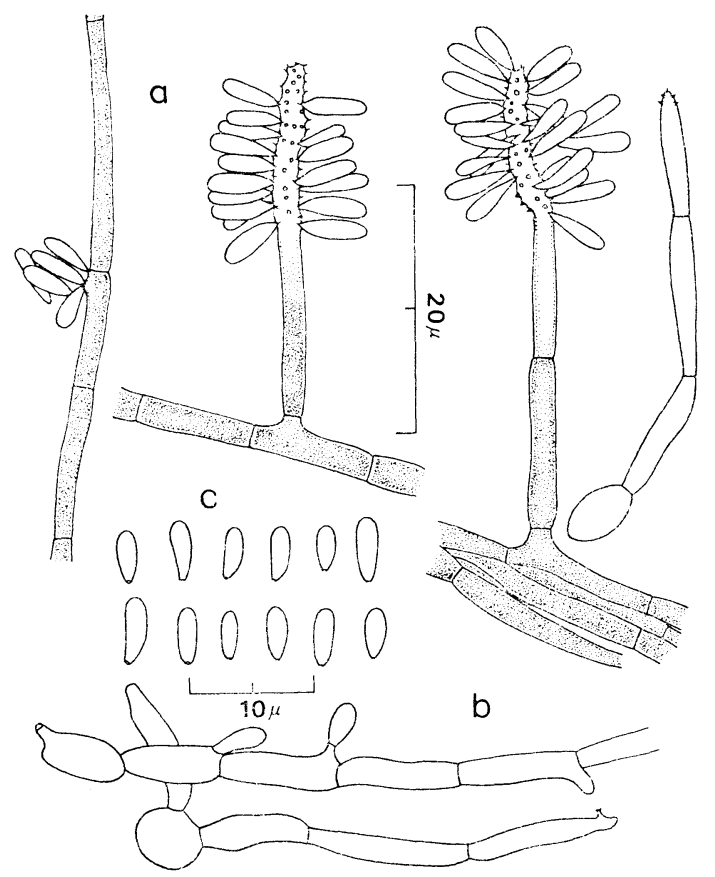

Fig. 6. Rhinocladiella elatior.

a. Various denticulate structures, b. Sprouting cells, c. Conidia.

Mycelium hyaline to pale brown, $1.5-3 \mu$ in diam., septate, branched, smooth-walled, detached or aggregated in funicles. Sporing structures mainly of denticulate type. Conidiophores hyaline to pale brown, arising as short branches from aerial hyphae or ropes of hyphae, $12-85 \times 1.5-3 \mu$, septate, simple or occasionally branched, increasing in length sympodially with numerous denticles; the denticulate zone terminal, sometimes with secondary proliferation. Conidia borne singly at the apex as blown out ends of the conidiophore, in acropetal succession, one-celled, hyaline, cylindrical to obovoid, $3.5-6(-7) \times 1-2 \mu$, smooth-walled, often with truncate base. Phialophora type not seen.

Cultures on potato-carrot agar growing restrictedly, umbonate, flocculent with rather abundant aerial hyphae, dark olive gray in color, conidial structures abundantly produced from tough basal felts or aerial hyphae, reverse olive black.

On oat-meal agar with wheat germ powder similar but growing somewhat more rapidly, greenish black, velvety and close-textured, reverse dark gray.

At $37^{\circ}$, growth is nil. 


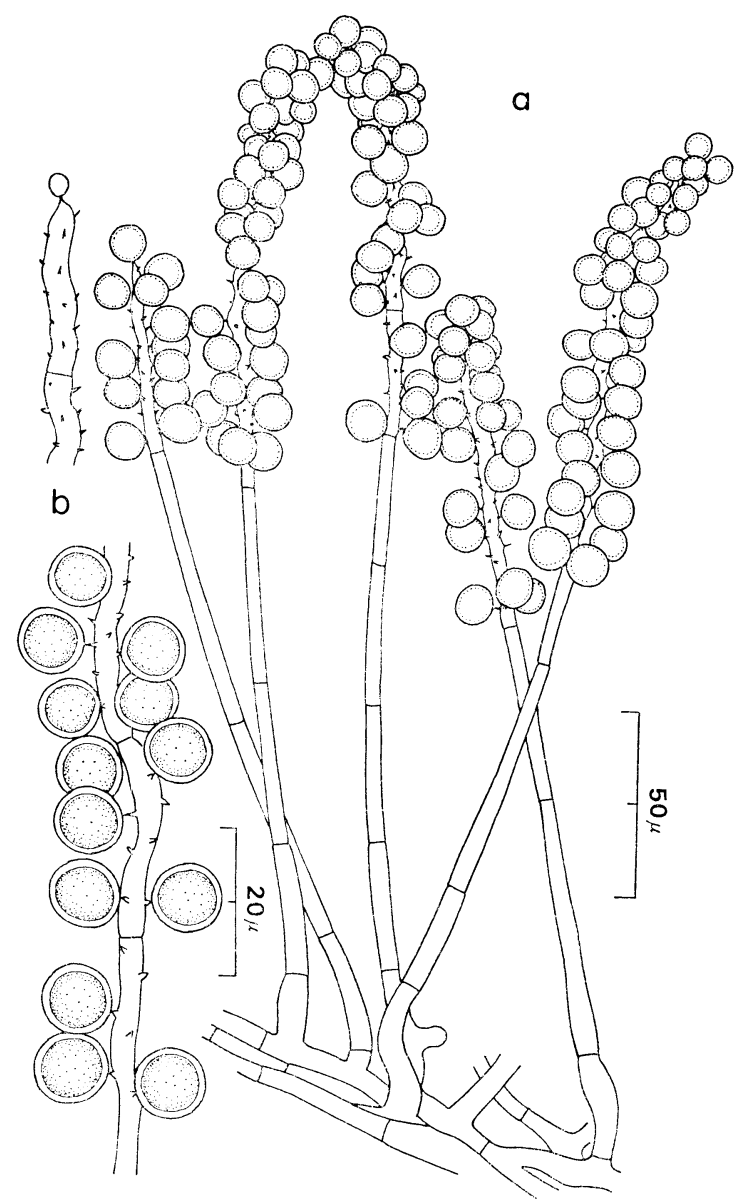

Fig. 7. Rhinotrichella globulifera.

a. Conidial structures, b. Terminal denticles and conidia.

Habitat: on Trametes dickinsii, Nikko National Park, Nikko-shi, Tochigi Pref., Japan, Oct. 30-31, 1969, NHL 2445.

This species is easily distinguished on the basis of the long denticulate conidiophores and the characteristic shape of the allantoid blastospores. It is being reported for the first time from Japan. R. clatior regularly occurs in soil and is commonly found upon decaying vergetation, including wood, sewage, and Polyporus.

Rhinstrichela slatlfere Amaud, in Bull. Soc. Mycol. France, 69, 272 (1953).

Cuitures on polypore infusion agar containing $1 \%$ sucrose spreading, thin 
vegetative mycelium submerged, with surface loose-textured to floccose, conidial structures scattered or sometimes concentrated in localized areas, at first pale yellow but developing yellowish brown shades.

Mycelium prostrate, hyaline, 5-10 $\mu$ in diam., septate, smooth-walled, branched. Conidiophores erect, arising from aerial hyphae or trailing hyphae, $350-650 \times 6-8 \mu$, pale yellow, smooth-walled, septate, simple or $1-2$ times branched in the lower parts, gradually tapering to the apical fertile regions measuring $3-3.6 \mu$ wide; the fertile regions more or less geniculate, with numerous denticulae on which solitary conidia are produced, reaching up to $180-400 \mu$ in length. Conidia of blastospore-type, acropleurogenous, unicellular, hyaline to pale yellow, globose to subglobose, $8-10(-11) \mu$ in diam., with a pointed base indicating the point of attachment, smooth-walled, at maturity breaking away from the sporogenous cells and leaving circular scars on the conidiophore wall in the fertile region.

At $37^{\circ}$, growth is nil.

Habitat: on Ganoderma tsugae and Inonotus dryateus, Otoineppu, Nakagawa-gun, Hokkaido, Japan, Sept. 6-8, 1969, NHL 2449.

Arnaud's original description of this species is too brief for certainty, but conidia are yellowish, definitely giobose and agree satisfactorily with his illustration. It is believed to be a new record for Japan.

Tritirachium dependens Limber, in Mycologia, 32, 26 (1940). (Figs. 8, 17)

Mycelium hyaline to pale yellowish brown, septate, branched, often aggregated in funicles. Conidiophores arising from the substratum or aerial hyphae, pale yellowish brown, erect, $360-500$ or more $\times 3-4 \mu$, septate, smooth-walled, verticillately branched, with $3-8$ whorls, $1-3$ branches in the whorl. Branches $10-35 \times 2-3 \mu$, simple or usually further branched in whorls of $2-6$ secondary or tertiary branches, measuring $10-25 \times 1.5-2.5 \mu$; the final branches carrying cylindrical sympodulae in verticils of 3-8. Sympodulae slender, slightly swollen near the base, tapering to a zigzagged, conidiumbearing portion, the base $10-12 \times 1.5-2 \mu$, the fertile part $8-30 \times 0.5-1 \mu$, bearing numerous scars indicating the insertion of conidia which have soon fallen away at maturity. Conidia borne terminally and laterally on the sporogenous cells, subglobose to broadly ovate, $2-3(-4) \times 1.5-3(-3.5) \mu$, pale yellowish brown, smooth-walled, often adhering together.

Colonies on oat-meal agar with wheat germ powder growing rapidly, plane, thin, at first grayish yellow brown, then becoming yellow brown, conidial structures abundantly produced, reverse dark brownish gray.

On potato-dextrose agar spreading broadly, velvety, consisting of a tough basal felt, conidial structures very abundant, arising from the basal felt, reverse dark brownish gray to nearly black.

At $37^{\circ}$, growth is nil.

Habitat: on Trametes dickinsii, Nikko National Park, Nikko-shi, Tochigi Pref., Japan, Oct. 30-31, 1959, NHL 2444. 


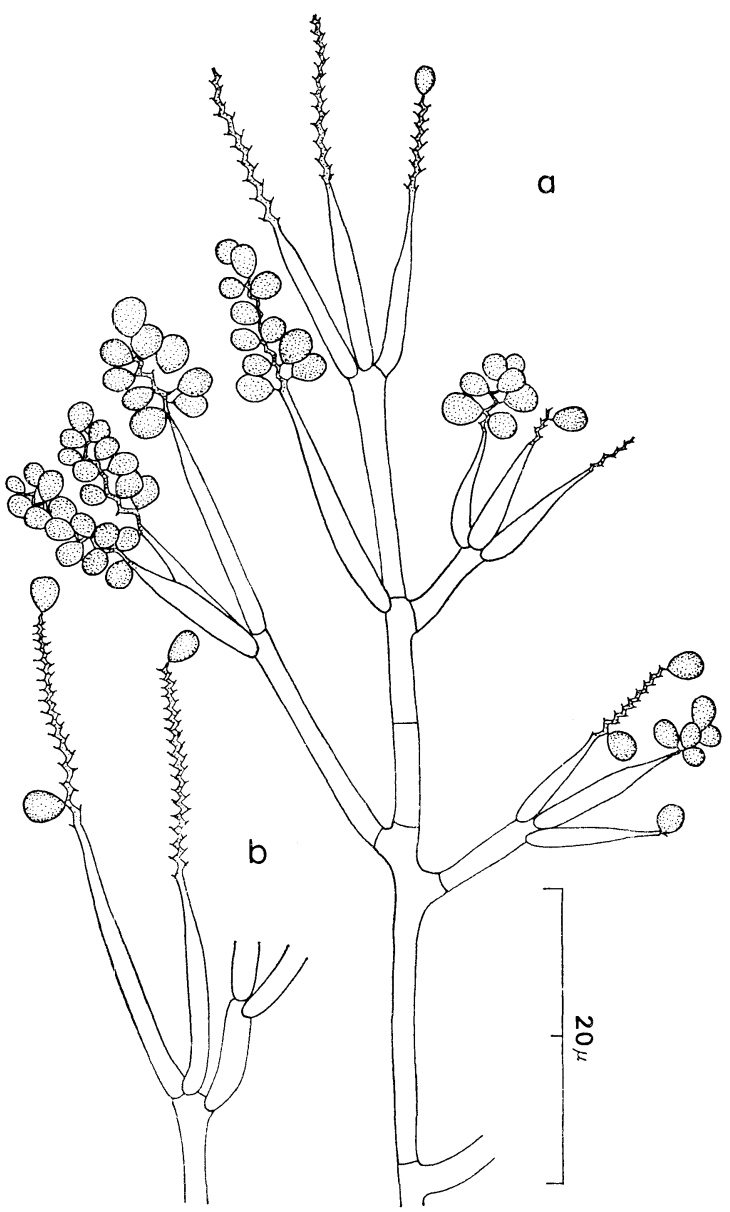

Fig. 8. Tritirachium dependens.

a. Conidial structure, b. Terminal denticles.

This species occurs regularly in and is fairly abundant upon substrata subject to dead plant tissues.

\section{ADDITIONAL RECORDS}

The following species have replaced by the hitherto reported descriptions.

Chaetomium cochliodes Palliser, in N. Amer. Flora, 3, 61 (1910); Udagawa, in J. Gen. Appl. Microbiol. Tokyo, 6, 240 (1960).

Habitat: on Coltricia cinnamomea, Otoineppu, Nakagawa-gun, Hokkaido, Japan, Sept. 6-8, 1969. 
Hypccrea fungiccla (Karst.) Sacc., in Syll. Fung., 2, 528 (1883); Doi, in Bull. Natl. Sci. Mus. Tokyo, 9, 352 (1966).

Hypocrea citrina var. fungicola Karst., 1873.

Habitat: on Inonotus dryateus, Otoineppu, Nakagawa-gun, Hokkaido, Japan, Sept. 6-8, 1969, and on Trametes dickinsii, Nikko National Park, Nikko-shi, Tochigi Pref., Japan, Oct. 30-31, 1969.

Recently, DoI (13) described H. fungicola from decayed Fomitopsis pinicola in Japan. According to him, the important distinguishing characters of this species from $H$. citrina are almost smooth, evenly divided, oval or cylindrical ascospores, Cephalosporium-type conidia, and granular layer of surface of stroma.

Microthecium retisporum Udagawa et Cain, in Can. J. Botany, 47, 1926 (1969).

Habitat: on Coriolus hirsutus, Otoineppu, Nakagawa-gun, Hokkaido, Japan, Sept. 6-8, 1969.

Calcarisporium arbuscula Preuss, in Linnaea, 24, 124 (1851); Tubaki, in Nagaoa, 5, 12 (1955).

Verticillium beauverioides Vincens, 1916; ?Cladobotryum binatum (Preuss) Linder, 1907; Cladobotryum elegans Arnaud, 1953.

Habitat: on Fomes fomentarius, Otoineppu, Nakagawa-gun, Hokkaido, Japan, Sept. 6-8, 1969.

This species is among the most common of all mycogenous fungi (NICOT, 14). In Japan, TUBAKI (3) reported its occurrence in Marasmius collection in Tokyo.

Scopulariopsis brevicaulis (Sacc.) Bainier, in Bull. Soc. Mycol. France, 23, 99 (1907); Tubaki, in Nagaoa, 5, 27 (1955).

Habitat: on Amanita virosa, Lactarius volemus, Cortinarius violaceus, and Trametes dickinsii, Otoineppu, Nakagawa-gun, Hokkaido, Japan, Sept. 6-8, 1969.

Figs. 9-11. Cleistothecia (9), asci (10) and conidial structures (11) of Cephalotheca splendens. (scales: Fig. 9, $500 \mu$; Figs. 10 and 11, $20 \mu$ )

Fig. 12. Coremium of Doratomyces microsporus. (scale $50 \mu$ )

Fig. 13. Coremia of Doratomyces putredinis. (scale $50 \mu$ )

Fig. 14. Conidial structures of Phialophora verrucosa. (scale $20 \mu$ )

Fig. 15. Conidial structures of Rhinocladiella elatior. (scale $20 \mu$ ) 


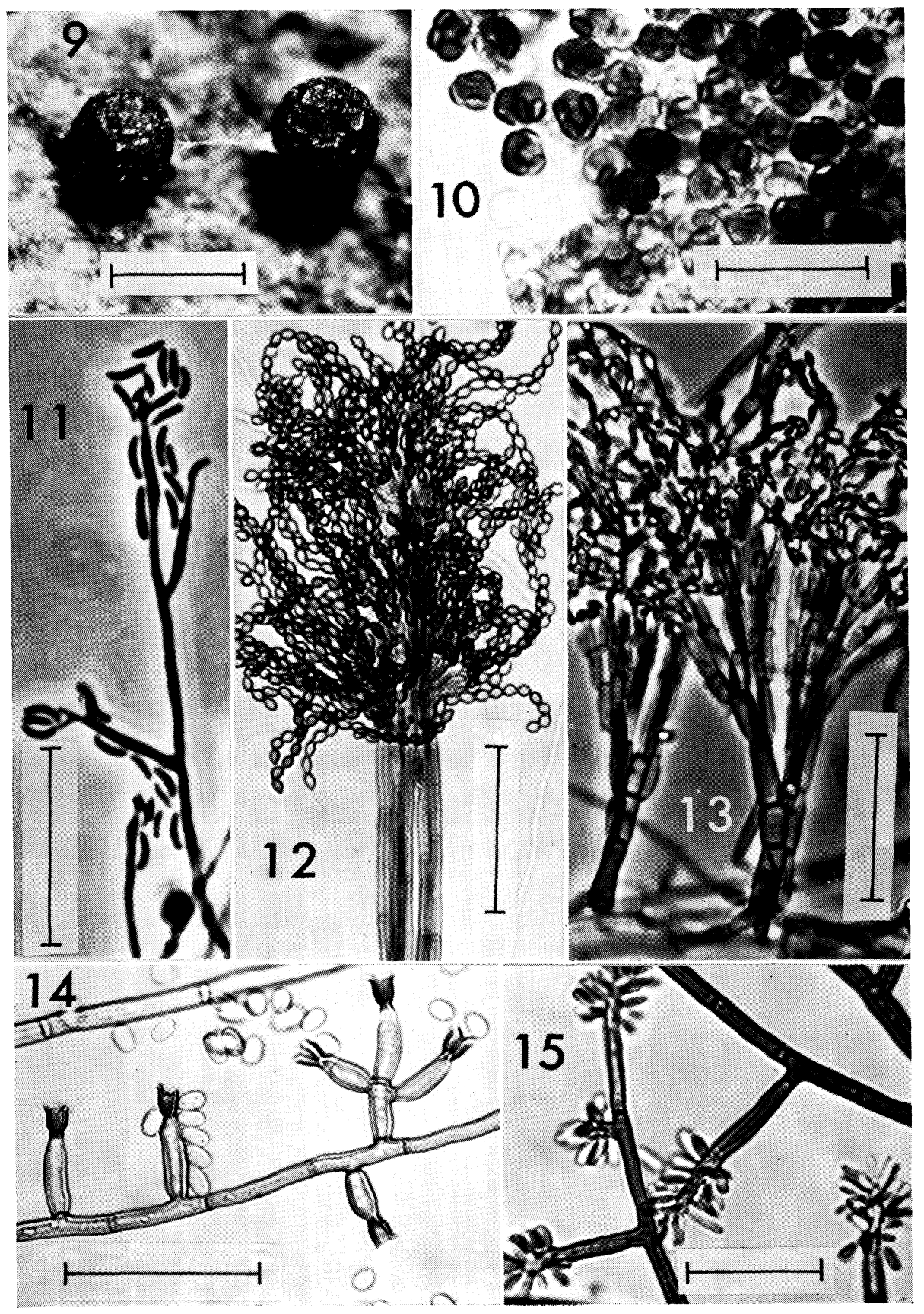




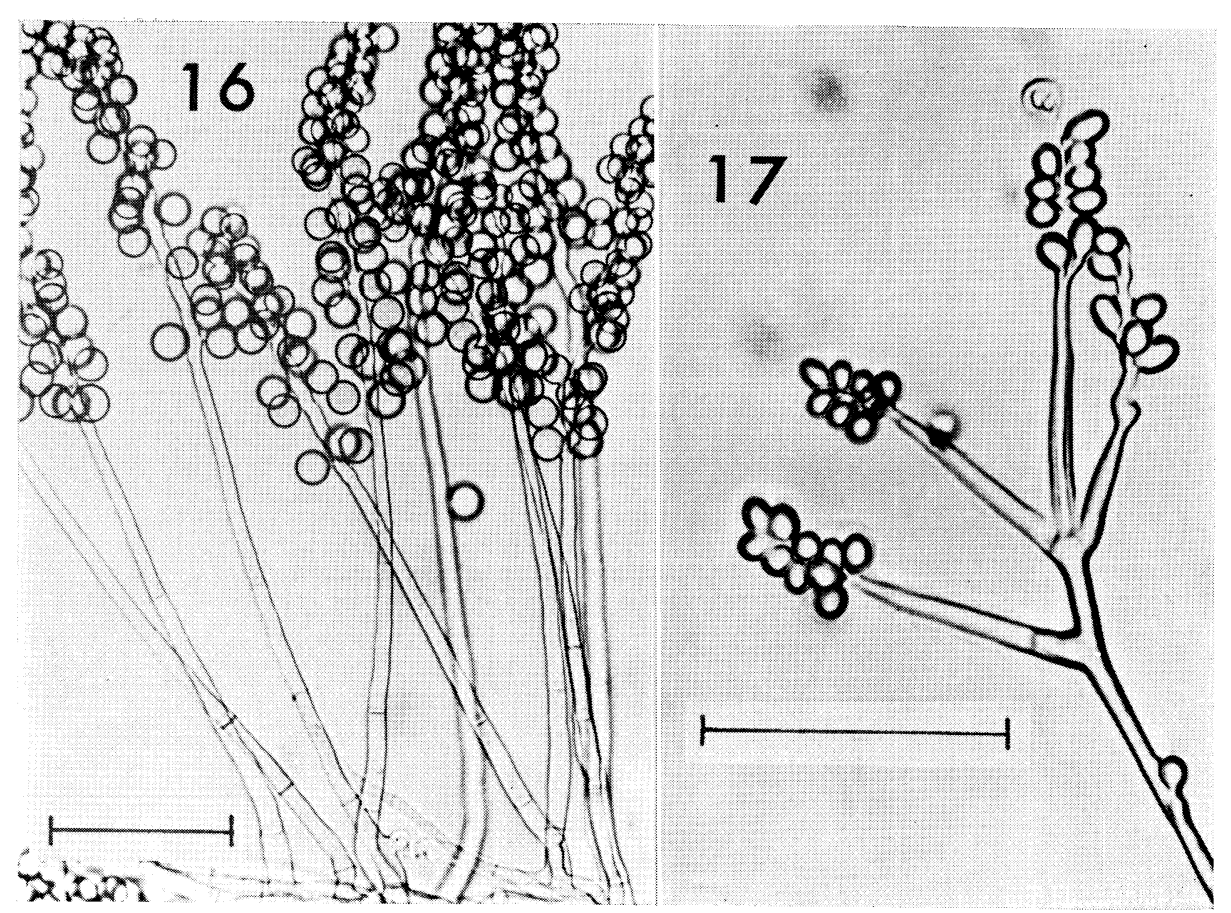

Fig. 16. Conidial structures of Rhinotrichella globulifera. (scale $50 \mu)$

Fig. 17. A terminal portion of conidial structure of Tritirachium dependens. (scale $20 \mu$ )

Scopulariopsis candida (Guéguen) Vuillemin, in Bull. Soc. Mycol. France, 27, 143 (1911); Tubaki, in Nagaoa, 5, 28 (1955) (cited as S. brevicaulis var. glabra).

Habitat: on Amanita virosa, Otoineppu, Nakagawa-gun, Hokkaido, Japan, Sept. 6-8, 1969.

Verticillium state of Nectria inventa Pethybridge, in Trans. Brit. Mycol. Soc., 6, 107 (1919); Hughes, in C.M.I. Mycol. Pap., 45, 3 (1951); Tubaki, in Nagaoa, 4, 2 (1954) (cited as Acrostalagmus cinnabarinus).

Habitat: on Inonotus dryateus, Otoineppu, Nakagawa-gun, Hokkaido, Japan, Sept. 6-8, 1969, and on Laccaria laccata var. proxima, Sugadaira, Sanada-machi, Chiisagata-gun, Nagano Pref., Japan, Oct. 2-3, 1969.

This conidial form was reported previously from Japan by TUBAKI (15) as coprophilous.

We are grateful to Prof. Komei Miyaki and Dr. Mikio Yamazaki, Chiba University, for their encouragement during this research. Our thanks are also due to Dr. Hiroshi 
Kurata and Dr. Keisuke Tubaki for their helpful suggestions, and Prof. Unji Hiura, University of Okayama, for providing photocopy of Richon's description, and Dr. J. Nicot, Museum National d'Histoire Naturelle, Paris, for private communication on Richon's specimen.

\section{REFERENCES}

1) G.R.W. ARnold, Z. Pilzkunde, 35 (1-2), 41 (1969).

2) J. Nicot, Rev. de Mycol., 31, 393 (1966) [1967].

3) K. Tubaki, Nagaoa, 5, 11 (1955).

4) M. Komatsu and Y. Hashioka, Rept. Tottori Mycol. Inst. Japan, 5, 12 (1966).

5) C. Bоoth, C.M.I. Mycol. Pap., 83, 1 (1961).

6) Ch. Richon, Bull. Soc. Mycol. France, 5, 103 (1889).

7) C.G.C. Chesters, Trans. Brit. Mycol. Soc., 19, 261 (1934).

8) D. Malloch and R.F. Cain, Can. J. Botany, 48, 1815 (1970).

9) K. Tubaki, In Y. Kobayasi, Yamagataken Sogo Gakujutsu Chosa, Shokubutsuhen, Kinrui, Yamagata (1964), p. 100 (in Japanese).

10) K. Sarto, J. Sci. Coll. Imp. Univ. Tokyo, 18 (5), 1 (1904).

11) M. Komatsu, Rept. Tottori Mycol. Inst. Japan, 7, 78 (1969).

12) V. Holubová-Jechová, Ceska Mykol., 23, 209 (1969).

13) Y. DoI, Bull. Natl. Sci. Mus. Tokyo, 9, 352 (1966).

14) J. Nicot, Bull. Soc. Mycol. France, 84, 85 (1968).

15) K. Tubaki, Nagaoa, 4, 1 (1954). 